\title{
REPEAT COMPARTMENT DECOMPRESSION WITH PARTIAL FASCIECTOMY
}

\author{
SIMON BELL \\ From Prince Henry's Hospital, Melbourne
}

\begin{abstract}
After having had a standard decompression for anterior compartment syndrome, five patients presented with persistent symptoms and pressure values above normal. A repeat procedure combined with fasciectomy relieved their pain; postoperative pressure values were normal.
\end{abstract}

Chronic compartment syndrome is a well-recognised cause of exercise-associated leg pain, and an intracompartmental pressure study is the accepted diagnostic test (Mubarak and Hargens 1981). The most successful treatment of the syndrome is operative decompression of the involved compartment, which is usually performed by making a longitudinal incision in the fascia. This has been described in detail by Rorabeck, Bourne and Fowler (1983), and most variations of the technique have been designed to decrease the size of the skin incisions (Reneman 1975; Wallensten 1983).

The reported results of anterior compartment decompression are generally good (Reneman 1975; Wallensten 1983). However, in a paper which discusses true failures, Puranen and Alavaikko (1981) report three patients with persistent symptoms as well as positive pressure studies after decompression; the authors concluded that the fascial split at the initial operation was not long enough and, at a repeat operation, a longer split was made. After this the symptoms in all three patients were relieved and pressure studies were normal.

There seem to have been no reported failures of full length decompression for chronic anterior compartment syndrome but this paper reports five such patients who, after adequate decompression, still had persistent symptoms and positive pressure studies. Their symptoms were relieved by a repeat decompression.

\section{PATIENTS AND METHODS}

Five healthy male patients with symptoms which had persisted for at least six months after anterior compartment decompression were evaluated and treated by the author over a three-year period (Table 1). Before the first operative procedure all had been troubled by anterior leg

Simon Bell, FRCS, FRACS, Orthopaedic Fellow

115 Grey Street, East Melbourne, Victoria 3002, Australia.

(C) 1986 British Editorial Society of Bone and Joint Surgery 0301-620X/86/5146\$2.00 pain on exercise, typical of chronic compartment syndrome; the diagnosis had been made clinically in four patients and by pressure studies in the fifth.

The author had performed one of the initial decompressions and assisted at another, while the two surgeons who had performed the remaining decompressions reported the details. In each patient, the fascia of the anterior compartment had been split along its entire length through a longitudinal skin incision. When exercise was resumed after the operation all patients were again troubled by the same leg pain, although two patients felt that they could exercise for longer before pain started.

Intracompartmental pressure studies of 22 control subjects had established the following normal values: resting pressure, $9 \mathrm{mmHg}(6-16)$; exercise pressure, $25 \mathrm{mmHg}$ (15-43). Recordings were made for each of the five patients in at least one of the previously decompressed anterior compartments; if a lateral or posterior compartment syndrome was suspected, pressure studies for these were also undertaken. Intracompartmental pressure was measured in the early cases using a wick catheter (Mubarak et al. 1976) while in later cases a slit catheter monitoring system was used (Rorabeck et al. 1981) (Howmedica, Rutherford, New Jersey). It has been shown that pressure measurements with the two systems are comparable (Shakespeare, Henderson and Clough 1981). The muscles of the anterior compartment were exercised with the patient supine, using a system of weights and pulleys similar to that described by Reneman (1975). Both the resting pressure and the maximal mean pressure during exercise were recorded.

A repeat decompression with partial fasciectomy of the involved compartments was then performed in all five patients.

Operative technique. A longitudinal skin incision at least $10 \mathrm{~cm}$ long was made in the centre of the anterior compartment; if possible, any previous scars were excised. The skin was undermined superficial to the deep fascia and the deep branch of the peroneal nerve 
Table I. Clinical data and pressure values of five patients who had a repeat decompression procedure and partial fasciectomy

\begin{tabular}{|c|c|c|c|c|c|c|c|c|}
\hline \multirow[b]{2}{*}{ Case } & \multirow[b]{2}{*}{ Age } & \multirow[b]{2}{*}{ Activity } & \multirow{2}{*}{$\begin{array}{l}\text { Compartment } \\
\text { previously } \\
\text { decompressed }\end{array}$} & \multirow{2}{*}{$\begin{array}{l}\text { Anterior } \\
\text { compartment } \\
\text { measured }\end{array}$} & \multicolumn{2}{|c|}{$\begin{array}{l}\text { Before repeat decompression } \\
(\mathrm{mm} H g)\end{array}$} & \multicolumn{2}{|c|}{$\begin{array}{l}\text { After repeat decompression } \\
\text { and partial fasciectomy } \\
\left(\mathrm{mm} \mathrm{H}_{\mathrm{g}}\right)\end{array}$} \\
\hline & & & & & $\begin{array}{l}\text { Resting } \\
\text { pressure }\end{array}$ & $\begin{array}{l}\text { Exercise } \\
\text { pressure }\end{array}$ & $\begin{array}{l}\text { Resting } \\
\text { pressure }\end{array}$ & $\begin{array}{l}\text { Exercise } \\
\text { pressure }\end{array}$ \\
\hline 1 & 32 & $\begin{array}{l}\text { Military } \\
\text { training }\end{array}$ & $\begin{array}{l}\text { Bilateral anterior } \\
\text { and lateral }\end{array}$ & Right & 15 & 90 & 12 & 39 \\
\hline 2 & 20 & Soccer & Bilateral anterior & $\begin{array}{l}\text { Right } \\
\text { Left }\end{array}$ & $\begin{array}{l}18 \\
32\end{array}$ & $\begin{array}{l}75 \\
90\end{array}$ & 11 & 38 \\
\hline 3 & 21 & $\begin{array}{l}\text { Australian } \\
\text { football }\end{array}$ & $\begin{array}{l}\text { Bilateral anterior } \\
\text { and posterior }\end{array}$ & Right & 20 & 92 & & \\
\hline 4 & 24 & Soccer & $\begin{array}{l}\text { Right anterior } \\
\text { and lateral }\end{array}$ & Right & 18 & 100 & 5 & 21 \\
\hline 5 & 25 & Soccer & $\begin{array}{l}\text { Left anterior } \\
\text { and lateral }\end{array}$ & Left & 24 & 65 & & \\
\hline
\end{tabular}

identified and preserved. A segment of fascia $15 \mathrm{~cm}$ long was excised, extending from the tibia medially to the junction with the peroneal compartment fascia laterally and the remaining anterior fascia was split along its entire length. The anterior intermuscular septum was then divided transversely down to the fibula, but the interosseous membrane was left intact.

Postoperatively the patients remained in bed for five days but were encouraged to begin active foot dorsiflexion one day after operation. Walking with crutches then began; these were discarded when the patient could walk without pain. At least six months after the operation, three of the patients had a further pressure study.

\section{RESULTS}

The intracompartmental pressure measurements for all five patients after their first decompression procedure gave high values consistent with chronic compartment syndrome (Table 1).

Six months after the repeat decompression with partial fasciectomy, no patient had leg pain during exercise and pressure studies in all three patients were normal (Table 1).

\section{CASE REPORT}

A 32-year-old man (Case 1, Table 1) had first felt bilateral leg pain during part-time military training; the pain had occurred after walking in boots for $5 \mathrm{~km}$ or running $100 \mathrm{~m}$ and had settled after resting a few minutes. He had initially presented two years after the onset of symptoms, and pressure studies of his right leg revealed $15 \mathrm{mmHg}$ at rest and $65 \mathrm{mmHg}$ during exercise. At the initial bilateral decompression through a $10 \mathrm{~cm}$ skin incision the anterior compartment fascia had been split along its entire length, and two transverse fascial incisions across the entire compartment were also made. The lateral compartments were also decompressed and a segment of the anterior compartment fascia was removed for microscopic study (Figs 1 and 2).

Eight months after operation the patient's symptoms had improved but he still felt the same leg pain when he ran more than $4 \mathrm{~km}$. A repeat pressure study of the right anterior compartment revealed a resting value of $15 \mathrm{mmHg}$ and an exercise value of $90 \mathrm{mmHg}$ and a second more radical compartment decompression with partial fasciectomy was advised.

At operation, the edges of the earlier fascial decompression were easily seen and were $2 \mathrm{~cm}$ apart. However, the gap between the edges of the previous fascial incision was filled with fibrous tissue as thick as the original fascia and a specimen was removed for microscopy (Figs 3 and 4). The longitudinal decompression incisions were indistinct areas of scar tissue. Postoperatively, the patient was symptom-free on exercise. A further pressure study was performed: the resting pressure was $12 \mathrm{mmHg}$, and the peak exercise pressure was $35 \mathrm{mmHg}$, well within normal limits.

\section{DISCUSSION}

A compartment decompression procedure has failed if the patient's symptoms persist and pressure studies remain positive (Rorabeck et al. 1983). The five cases presented in this article had all had standard decompressions with a full length fascial split. During healing, fibrous scar tissue may grow between the two cut fascial edges and may then act as a new fascia; the quality and quantity of this new tissue seems not to have been previously reported. In the reported case histological investigations showed reactive fibrosis (Figs 3 and 4). Macroscopically this tissue was substantial and it may have been as resistant to any swelling of the compartment as normal fascia. The reason for true failure with persistent symptoms and high pressure values after apparently adequate compartment decompression seems to be that the new size of the anterior compartment is still too small. A number of factors may contribute to this: new fibrous tissue may grow too quickly and too strongly between the cut edges of the old fascia, and if the patient rests for too long after decompression, muscle bulk in the compartment may decrease so that the healed compartment cannot accommodate renewed muscle hypertrophy.

Despite an apparently adequate initial operation and postoperative management, the five patients presented in this article had persistent pain. However, after a second compartment decompression with partial 


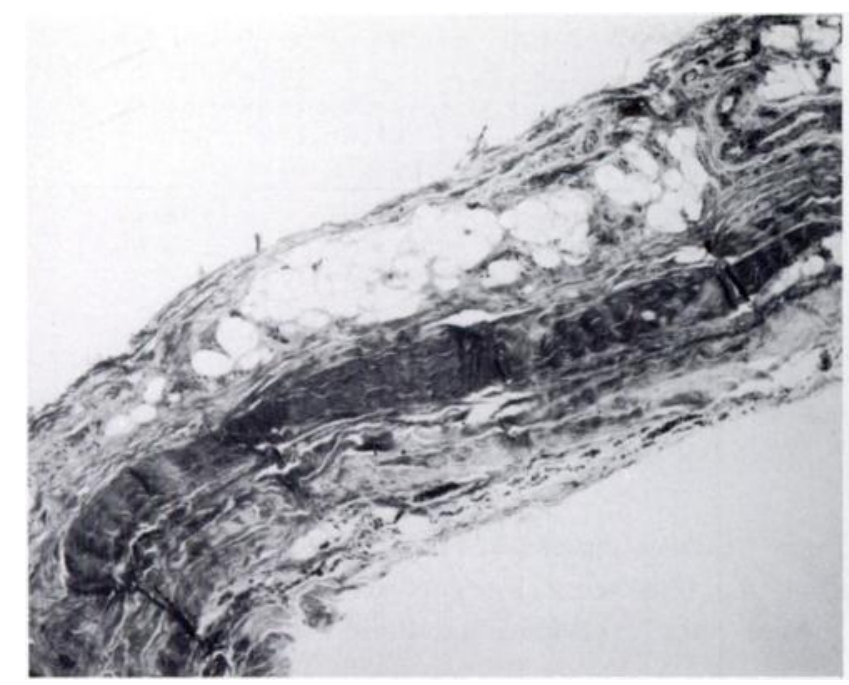

Fig. 1

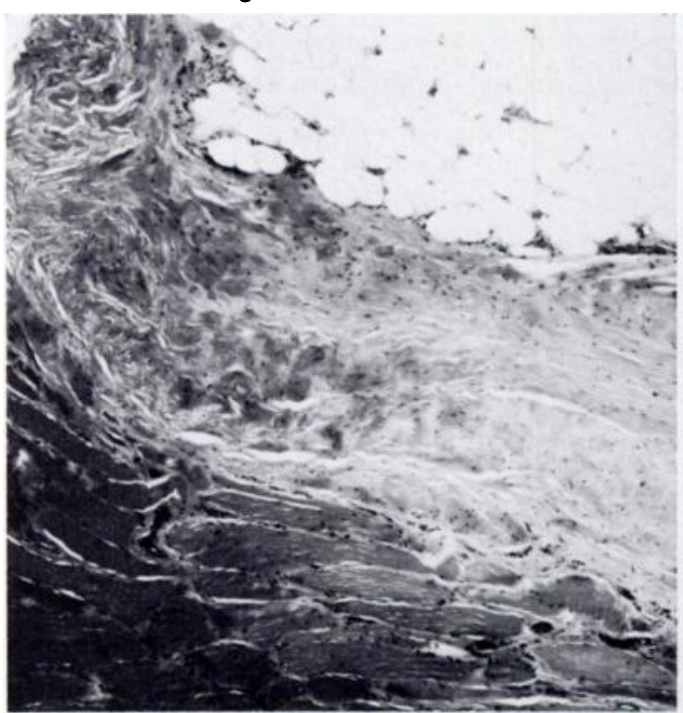

Fig. 3

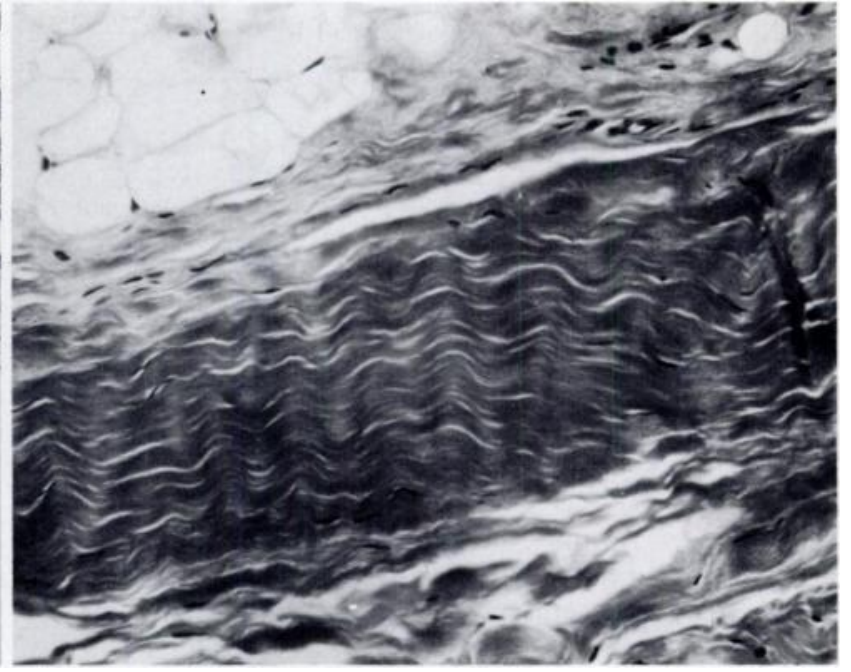

Fig. 2

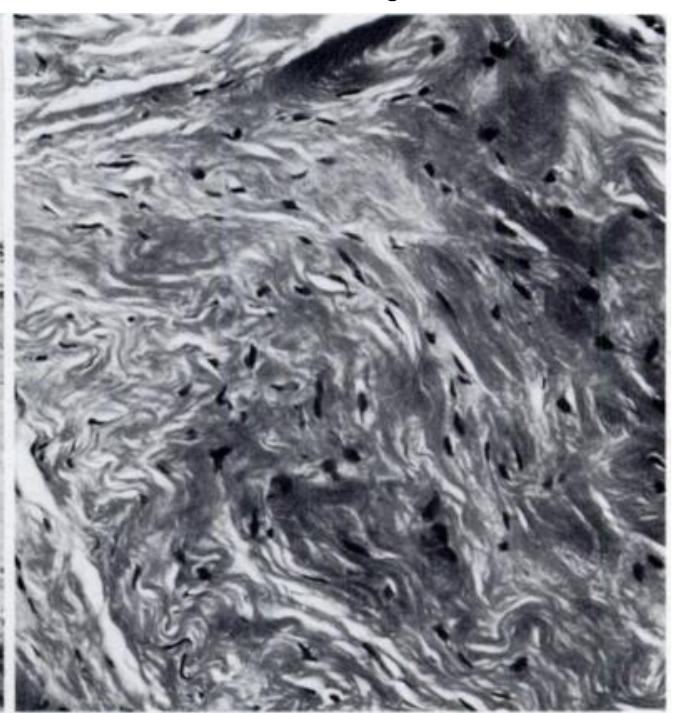

Fig. 4

Figure 1 - Original compartment fascia showing a thin sheet of hypocellular collagen $(\mathrm{H} \& \mathrm{E} \times 45)$. Figure $2-\mathrm{A}$ higher magnification shows orderly alignment of fibroblasts in fascia $(H \& E \times 180)$. Figure $3-$ Reactive fibrosis at the site of previous fasciectomy forms a thickened dense scar with re-establishment of fascial plane continuity (H \& E x 45). Figure 4-A higher magnification shows a disordered alignment of fibroblasts in scar tissue (H \& E $\times 180)$.

fasciectomy, all were symptom-free. It is not known whether equally good results could have been obtained by simply splitting the fascia again, but it seems reasonable to assume that fibrous scar tissue forming over a larger defect will be weaker and result in a relatively larger compartment. When an initial compartment decompression has failed, partial fasciectomy appears to be a helpful addition to any repeat operation.

The author expresses his gratitude to Dr H. Reiman, Surgical Pathologist of the Mayo Clinic, for advising on the histopathology.

\section{REFERENCES}

Mubarak SJ, Hargens AR, Owen CA, Garetto LP, Akeson WH. The Wick catheter technique for measurement of intramuscular pressure: a new research and clinical tool. J Bone Joint Surg [Am] $1976 ; 58-A: 1016-20$.
Mubarak SJ, Hargens AR. Compartment syndromes and Volkmann's contracture. Saunders Monographs in Clinical Orthopaedics 3. Philadelphia etc: WB Saunders, 1981.

Puranen J, Alavaikko A. Intracompartmental pressure increase on exertion in patients with chronic compartment syndrome in the leg. J Bone Joint Surg [Am] $1981 ; 63-A: 1304-9$.

Reneman RS. The anterior and lateral compartmental syndrome of the leg due to intensive use of muscles. Clin Orthop 1975;113:69-80.

Rorabeck CH, Castle GSP, Hardie R, Logan J. Compartmental pressure measurements: an experimental investigation using the slit catheter. J Trauma $1981 ; 21: 446-9$.

Rorabeck CH, Bourne RB, Fowler PJ. The surgical treatment of exertional compartment syndrome in athletes. J Bone Joint Surg [Am] 1983:65-A :1245-51.

Shakespeare DT, Henderson NJ, Clough G. The slit catheter: a comparison with the Wick catheter in the measurement of compartment pressure. Injury 1981;13:404-8.

Wallensten R. Results of fasciotomy in patients with medial tibial syndrome or chronic anterior-compartment syndrome. J Bone Joint Surg [Am] 1983;65-A:1252-5. 